\title{
Enzymatic Extraction and Characterization of Lipid Fraction Highly Rich in Omega-3 Fatty Acids from Mackerel (Scomber scombrus)
}

\author{
GBOGOURI Grodji Albarin ${ }^{1, *}$, WAZE Aimée Mireille Alloue-Boraud ${ }^{2}$, GONNETY Tia Jean ${ }^{3}$, LINDER Michel ${ }^{4}$ \\ ${ }^{1}$ Department of Food Science and Technology, Laboratory of Nutrition and Food Safety Nangui Abrogoua University, Côte d'Ivoire \\ ${ }^{2}$ Department of Food Science and Technology, Laboratory of Microbiology and Molecular Biology, \\ Nangui Abrogoua University, Côte d'Ivoire \\ ${ }^{3}$ Department of Food Science and Technology, Laboratory of Biocatalysis and Bioprocess, Nangui Abrogoua University, Côte d'Ivoire \\ ${ }^{4}$ Laboratory of Biomolecular Engineering, École Nationale Supérieure d'Agronomie et des Industries Alimentaires (ENSAIA), \\ University of Lorraine, Vandoeuvre Cedex, Franc \\ *Corresponding author: albaringrodji@yahoo.fr
}

\begin{abstract}
Fresh mackerel heads were submitted to enzymatic hydrolysis using Alcalase $2.4 \mathrm{~L}\left(60^{\circ} \mathrm{C}, 2 \mathrm{~h}\right)$. The centrifugation of the slurry displayed three lipid fractions. Chemical characteristics of these fractions showed significant differences for protein, lipid and ash contents. The rate of oil released after enzymatic extraction accounted for $19.20 \%$ and $21 \%$ for $3 \% \mathrm{E} / \mathrm{S}$ and $5 \% \mathrm{E} / \mathrm{S}$ respectively with no significant difference $(\mathrm{p}<0.05)$. Lipids released after enzymatic processes, lipids from emulsified fraction displayed similar lipid classes level amounted to $95-98 \%$ for triglycerides (TG) and $2-5 \%$ for phospholipids (PL). As for heavy fraction, there were $42 \%$ of TG and $58 \%$ of PL. Lipids released by enzymatic hydrolysis and lipids of emulsified fraction displayed similar content of PUFA and were compared to lipids extracted by solvent. The main PUFA were EPA (6.99 to 7.56\%) and DHA (from 11.26 to $15.86 \%$ ). The lipid of the heavy fraction, which contained the most abundant amount of the DHA accounted for $26.11 \%$ and a high amount of EPA $(7.73 \%)$.
\end{abstract}

Keywords: mackerel, docosahexaenoic acid, fish oil, omega 3 polyunsaturated fatty acids, enzymatic extraction

Cite This Article: GBOGOURI Grodji Albarin, WAZE Aimée Mireille Alloue-Boraud, GONNETY Tia Jean, and LINDER Michel, "Enzymatic Extraction and Characterization of Lipid Fraction Highly Rich in Omega-3 Fatty Acids from Mackerel (Scomber scombrus)." American Journal of Food and Nutrition, vol. 6, no. 3 (2018): 76-82. doi: 10.12691/ajfn-6-3-3.

\section{Introduction}

Fish are a source of high quality lipids, protein, vitamins and essential minerals, but, above all, a virtually unique, rich source of omega-3 long-chain poly-unsaturated fatty acids (PUFA).

Fish lipids are particularly rich in the long-chain omega-3 polyunsaturated fatty acids family, mostly represented by eicosapentaenoic acid (EPA, C20: n-3) and docosahexaenoic acid (ADH, C22: $6 \mathrm{n}-3)$ and micronutrients such as vitamin $A$, vitamin $D$, calcium, magnesium, phosphorus [1-3]. These lipids are receiving a lot of attention because of the health benefits associated with high levels of the long chain omega-3 polyunsaturated fatty acids (PUFA) eicosapentaenoic acid (EPA) and docosahexaenoic acid (DHA). Decreased rates of cardio-vascular disease have been noted in populations with high fish consumption, such as Alaskan Natives [4,5]. High levels of DHA are found in brain tissue and DHA is essential during brain development and retina formation of infants [6].

The $n-3$ polyunsaturated fatty acids further promote the development of the central nervous system of the foetus
$[7,8]$. Some studies have shown the anti-inflammatory properties of fish oils in general $[9,10]$.

The study conducted by Nabila et al., [11] showed a phospholipopeptidic complex obtained by the enzymatic hydrolysis of salmon heads in green conditions; exert anxiolytic-like effects and neuroprotective properties in a time and dose-dependent manner, with no affection of locomotor activity. The use of food enzymes, especially proteases, has been a considerable success in modern techniques of fish protein and lipid valorisation. It is a less expensive and relatively easy process to control, resulting in the production of products with functional and nutritional properties particularly interesting for the food, pharmaceutical and cosmetic industries $[2,12,13]$.

Mackerel, jawfish, tilapia and tuna are much consumed in Côte d'Ivoire. They play an important role in human nutrition owing to their nutritional qualities based on high proteins content, lipid quality, and mineral content [14]. Fish also offers a wide choice of taste and texture or shape, depending on how it is marketed: whole or in net, frozen, salted, smoked, dried or processed (preserves, prepared dishes, surimi). In Côte d'Ivoire, fish-based dishes such as the semolina of cassava locally named "Attiéké", with smoked or grilled mackerel, are much consumed by the 
Ivorian public. Despite the availability of these fishes, there is a lack of data about the quality of oils of fishes locally consumed. In addition, no research work has been carried out on the enzymatic fish lipids extraction nor about the polyunsaturated rich lipid from fish.

The objective of this study is to perform the enzymatic extraction of the lipid fraction rich in PUFA n-3, especially docosahexaenoic acid, using proteolysis assisted by Alcalase 2.4L.

\section{Material and Methods}

\subsection{Material}

The experiments were carried out on Mackerel heads (Scomber scombrus), obtained from the Port Autonome d'Abidjan (Côte d'Ivoire). Regularly preserved at $-20^{\circ} \mathrm{C}$, the fish was removed from the freezer and crushed at $+4^{\circ} \mathrm{C}$ with a domestic grinder (S.A.S. Groupe SEB Moulinex, Ecully France). The food grade enzyme used was Alcalase 2.4L (2.4 AU/g and a density of $1.18 \mathrm{~g} / \mathrm{ml})$, a bacterial endopeptidase from Bacillus licheniformis (Novozymes, Denmark). All other chemicals used were of analytical grade.

\subsection{Methods}

\subsubsection{Lipid Extraction by Enzymatic Hydrolysis}

The enzymatic hydrolysis was performed according to Gbogouri et al., method [2]. $500 \mathrm{~g}$ of the crushed Mackerel heads was suspended in distilled water and put in a stirred thermostated reactor $(2 \mathrm{~L})$. The adjustment of $\mathrm{pH}$ with $\mathrm{NaOH} 4 \mathrm{M}$ was done for 15 min under mixing. The enzyme solution was then added and the reaction allowed for $2 \mathrm{~h}$ under nitrogen and constant agitation at $600 \mathrm{rpm}$. The $\mathrm{pH}$ was kept constant by automatically adding $\mathrm{NaOH} 4 \mathrm{M}$ during hydrolysis according to the $\mathrm{pH}$-stat method. The volume of $\mathrm{NaOH}$ was recorded to allow calculation of the degree of hydrolysis (DH).

The medium was coarsely filtered to retain bones, whereas the liquid phase was subjected to subsequent centrifugation to separate the oil, the emulsion fraction and the sludge from the underlying aqueous phase. Enzymes were inactivated in the hydrolysates by the heat treatment with microwave at $95^{\circ} \mathrm{C} / 5 \mathrm{~min}$. The emulsion fraction and the sludge were freeze-dried subsequently and were stored under nitrogen at $-20^{\circ} \mathrm{C}$. This experiment was done in triplicate.

\subsubsection{Proximate Composition Analyses}

Crude protein was analyzed using the Kjeldahl Method [15], with nitrogen analyzer (Gerhadt Vapodest, 50, Germany). Dry matter was determined gravimetrically after drying a sample overnight at $105^{\circ} \mathrm{C}$. Lipid content was determined using the method of Folch et al., [16]. Ash was quantified after incinerating the sample in the muffle furnace at $550^{\circ} \mathrm{C}$ overnight and minerals (potassium, iron, sodium, calcium, magnesium) were analyzed by atomic absorption spectrophotometry (Perkin Elmer, Model 1100, Paris, France) following the method used by Idouraine et al., [17].

\subsubsection{Lipid Class Analysis}

The lipid classes of lipid fraction were determined by Iatroscan MK-5 Thin Layer Chromatography-FID (Iatron Laboratories Inc., Tokyo, Japan). The first migration step in hexane, diethyl ether and formic acid (80:20:0.2, v:v:v), was carried out to determine the percentage of neutral and polar lipid fractions. The second migration in chloroform, methanol and ammoniac (65:35:5, v:v:v) defines the composition and percentage of polar lipid's classes. All standards were purchased from Sigma (Sigma-Aldrich $\mathrm{GmbH}$, Germany). Area percentages were expressed as the mean value of five repetitions.

\subsubsection{Fatty acid Composition}

Fatty acid methyl esters (FAMEs) from fish lipid fractions were prepared according to AOAC method [18]. The transmethylation was performed using $1 \mathrm{~mL}$ of $\mathrm{BF} 3$ in methanol $(14 \%, \mathrm{w} / \mathrm{v})$ and $1 \mathrm{~mL}$ of toluene at $100^{\circ} \mathrm{C}$. After the extraction of FAMEs with cyclohexane, they were washed with distilled water and analysed with a split mode by gas chromatography (CG-2010 Plus, Shimadzu) equipped with a flame ionization detector and a capillary column (60 m, $0.25 \mathrm{~mm}$ i.d. $\times 0.20 \mu \mathrm{m}$ film thicknesses). Oven temperature was set at $200^{\circ} \mathrm{C}$, detector and injector temperatures were at $250^{\circ} \mathrm{C}$. Helium was the carrier gas at a flow rate of $0.79 \mathrm{ml}$. min-1. A temperature program of column was initially set at $120^{\circ} \mathrm{C}$ for $2 \mathrm{~min}$, then rose to $180^{\circ} \mathrm{C}$ for $2 \mathrm{~min}$ at a rate of $2^{\circ} \mathrm{C} / \mathrm{min}$ and kept at $220^{\circ} \mathrm{C}$ for 25 minutes. FAMEs (PUFA1 and PUFA2 from marine source; Supelco, Sigma- 5 Aldrich, Bellefonte, PA, USA) were used as standards to identify fatty acids. The percentage of FAMEs was calculated from the total area of all peaks. The results were presented as triplicate analyses.

\subsection{Statistical Analysis}

All experiments were carried out in triplicates. Results were stated as the mean \pm standard deviation of several samples. The data obtained were subjected to one-way analysis of variance (ANOVA), followed by the Duncan's multiple range test to determine the significant difference between sample at $\mathrm{p}<0.05$ level using the SPSS program (SPSS Version 16.0).

\section{Result}

\subsection{Enzymatic Hydrolysis}

The hydrolysis of mackerel head protein was performed by Alcalase $2.4 \mathrm{~L}$ using two enzyme concentrations (3.0 and $5.0 \% \mathrm{E} / \mathrm{S}$ ) and the reaction times of 2 hours. The Degree of Hydrolysis (DH) obtained was $21 \%$ and $27 \%$ for $3 \% \mathrm{E} / \mathrm{S}$ and $5 \% \mathrm{E} / \mathrm{S}$ respectively (Figure 1).

\subsection{Extraction Rate of Fractions}

After hydrolysis of fish proteins, the mixture displayed four fractions after centrifugation (Figure 2). In this photography, there are lipid fractions (upper oil, light lipid) 
and protein fractions (the aqueous fraction and the heavy fraction). The recovery of the fraction was shown in Table 1 . The oil released was about $19.20 \%$ and $21 \%$ for $3 \% \mathrm{E} / \mathrm{S}$ and $5 \% \mathrm{E} / \mathrm{S}$ respectively with no significant difference $(\mathrm{p}<0.05)$. For oil content of the sludge fraction, the extraction of $3 \% \mathrm{E} / \mathrm{S}$ resulted in more oil content $(6.22 \%)$ of heavy fraction than the extraction of $5 \% \mathrm{E} / \mathrm{S}$ (up to $4.5 \%$ of oil content).

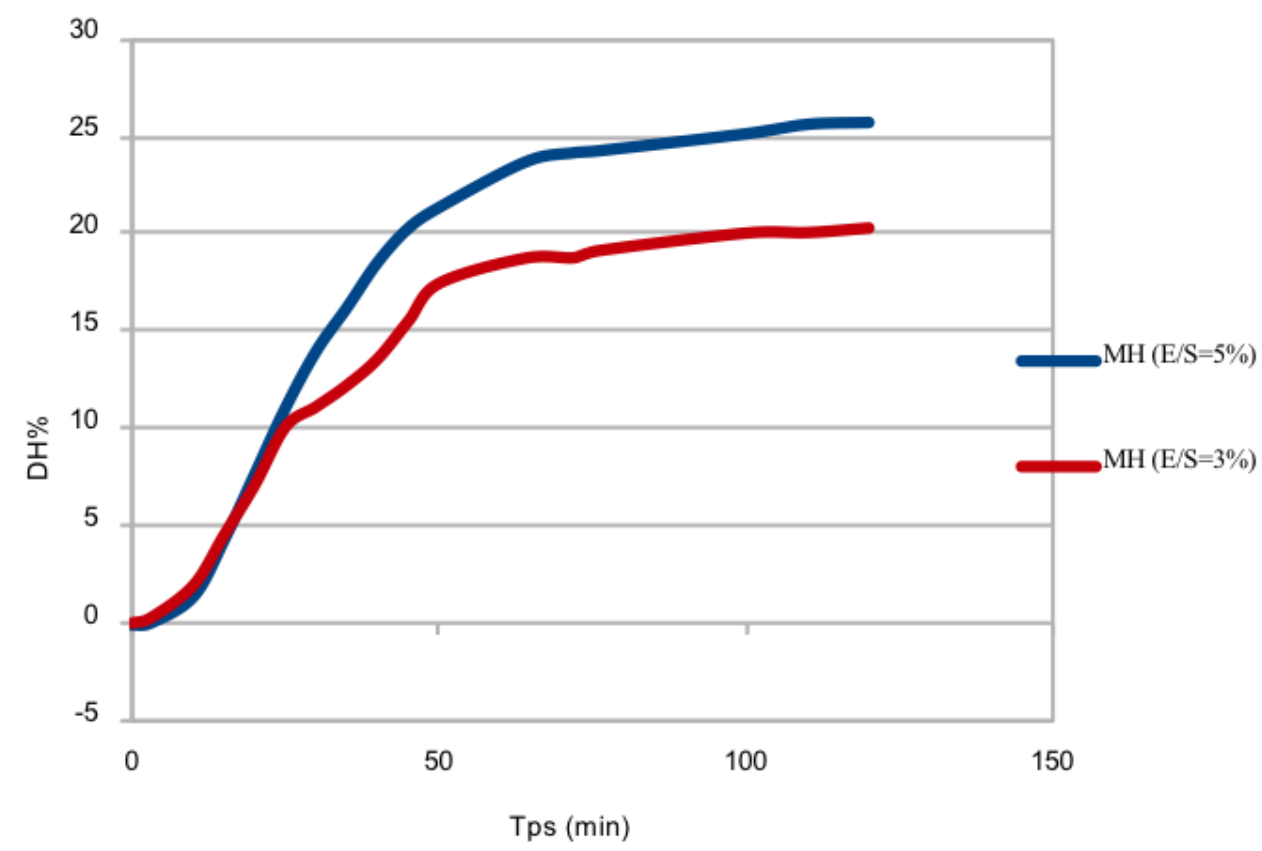

Figure 1. Enzymatic hydrolysis of protein of Mackerel Head (MH) by Alcase $2.4 \mathrm{~L}$ protease at $\mathrm{E} / \mathrm{S}$ ratio of 3 and $5 \%$

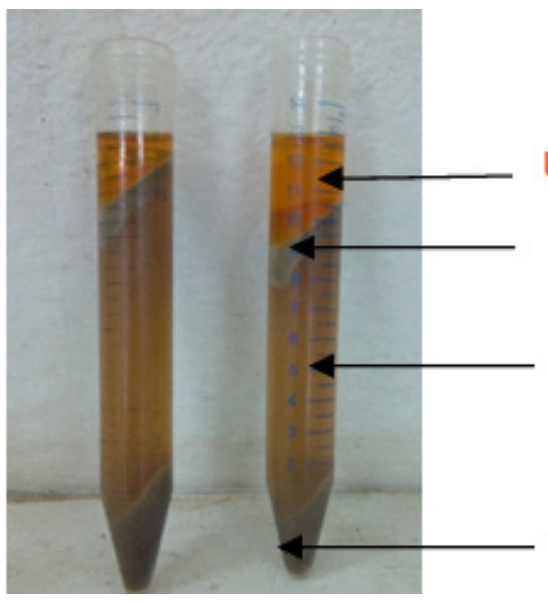

\section{Upper oil}

Emulsified fraction

Aqueous fraction

Heavy fraction

Figure 2. Photography of fractions obtained after centrifugation of the hydrolysate

Table 1. Rate ( $\mathrm{g} / \mathbf{1 0 0} \mathrm{g}$ of flesh) of the oil fractions obtained by enzymatic extraction

\begin{tabular}{llll}
\hline & Enzymatic extraction at E/S:3\% & Enzymatic extraction at E/S: $5 \%$ & $p$-value \\
\hline Oil fraction $(\mathrm{g})$ & $19.2 \pm 0.40^{\mathrm{a}}$ & $21.0 \pm 0.2^{\mathrm{a}}$ & $<0.001$ \\
Emulsified fraction $(\mathrm{g})$ & $0.9 \pm 0.05^{\mathrm{b}}$ & $0.3 \pm 0.02^{\mathrm{b}}$ & $<0.001$ \\
Heavy fraction $(\mathrm{g})$ & $6.2 \pm 0.2^{\mathrm{c}}$ & $4.5 \pm 0.4^{\mathrm{d}}$ & 0.123 \\
\hline
\end{tabular}

Data are means with standard deviations of triplicate values. Values not sharing a common superscript differ significantly.

Table 2. Chemical characteristics of mackerel head and fractions extracted by enzymatic method (g/100g of fresh matter) at E/S:5\%

\begin{tabular}{llllll}
\hline Component & Crude mackerel head & Oil fraction & Emulsified fraction & Heavy fraction & $p$-value \\
\hline Moisture (\%) & $57.22 \pm 2,22^{\mathrm{b}}$ & $1.52 \pm 0.41^{\mathrm{a}}$ & $60.0 \pm 2.5^{\mathrm{a}}$ & $54.85 \pm 2.8^{\mathrm{e}}$ & $<0.001$ \\
Protein (\%) & $16.62 \pm 0,41^{\mathrm{a}}$ & $0.0 \pm 0.0^{\mathrm{c}}$ & $20.0 \pm 1.5^{\mathrm{b}}$ & $17.24 \pm 2.0^{\mathrm{a}}$ & $<0.001$ \\
Lipid (\%) & $21.02 \pm 1,60^{\mathrm{a}}$ & $98.20 \pm 1.2^{\mathrm{b}}$ & $18.30 \pm 0.45^{\mathrm{a}}$ & $13.6 \pm 2.2^{\mathrm{c}}$ & $<0.001$ \\
Ash (\%) & $4.17 \pm 0,13^{\mathrm{b}}$ & $0.33 \pm 0,10^{\mathrm{a}}$ & $0.21 \pm 0.10^{\mathrm{a}}$ & $3.24 \pm 0.01^{\mathrm{b}}$ & $<0.001$ \\
\hline
\end{tabular}

Data are means with standard deviations of triplicate values. Values not sharing a common superscript differ significantly. 


\subsection{Chemical Characteristic of Lipid Fractions}

The proximate composition shown in Table 2, indicated that the raw material contained high amounts of proteins and lipids up to $16.62 \%$ and $21.02 \%$ respectively. The emulsified and the sludge fraction are also rich in protein with the content higher than the raw material. The crude mackerel head and the heavy fraction have high content of mineral, $4.17 \%$ and $3.24 \%$, respectively. The emulsified fraction and the heavy fraction have high lipid content.

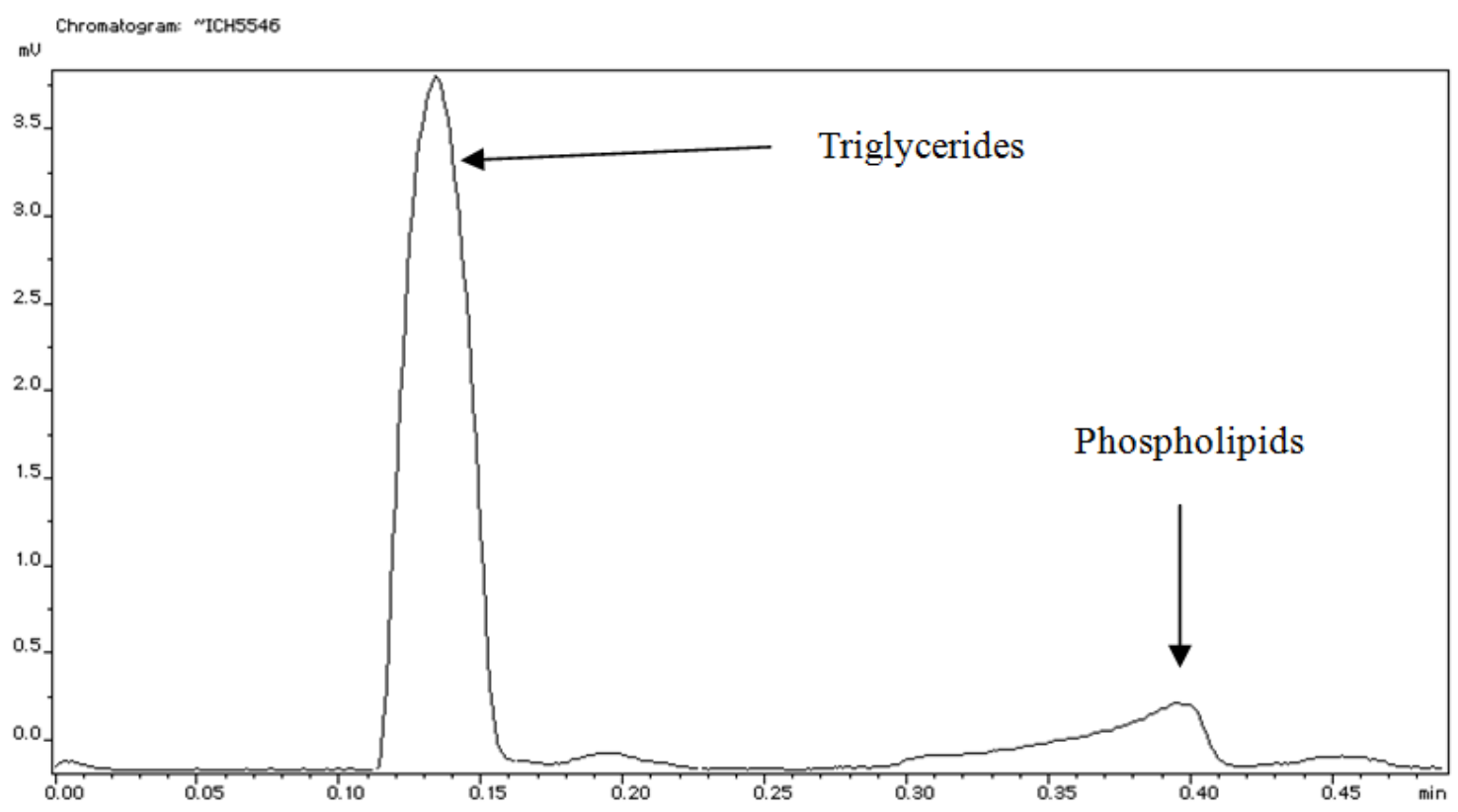

Figure 3. Lipid class profile of lipid extract assisted by Alcalase 2.4L, analyzed by TLC Iatroscan ${ }^{\circledR}$

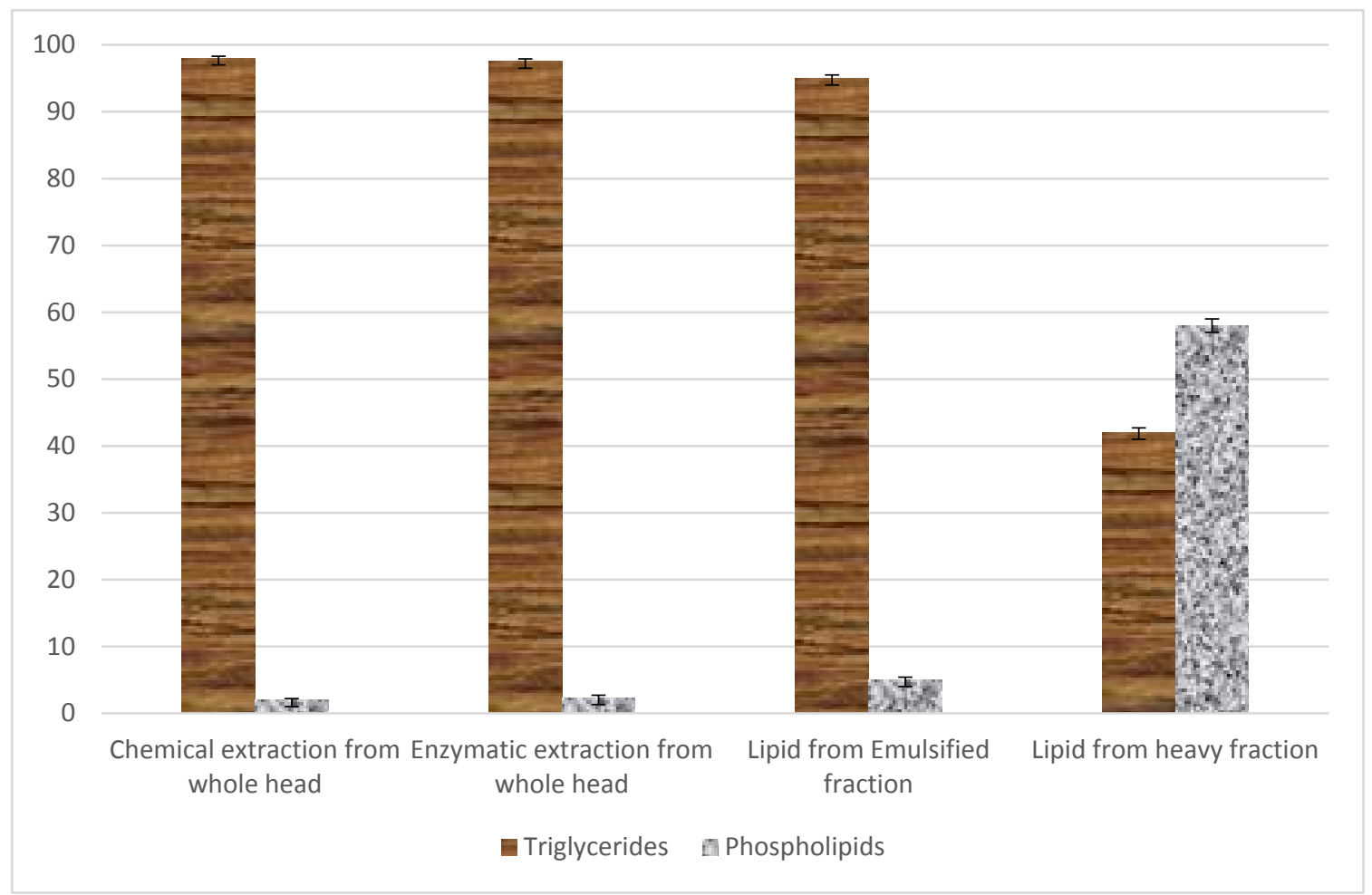

Figure 4. Proportion of the Lipid class from oil fraction analysed by TLC Iatroscan ${ }^{\circledR}$

\subsection{Lipid Class of the Extracted Fractions}

Figure 3 shows the lipid class composition of the different fractions analysed by the Thin Layer Chromatography (TLC) coupled to FID Iatroscan ${ }^{\circledR}$. The fractionation of the lipid shows two classes of lipids: the triglycerides (TG) and the phospholipids (PL). As shown in Figure 4, the lipid extracted by the enzyme has the same composition of triglycerides (97-98\%) and phospholipids (2-3\%) than the lipid extracted using solvent $(\mathrm{p}>0.05)$. For the emulsified fraction, the TG content accounted for $95 \%$ and the PL content for $5 \%$. However, for the lipid extracted from heavy fraction, there are $42 \%$ of TG and $58 \%$ of PL, that is significantly different compared to the other fractions. 
Table 3. Fatty acids composition of lipid fractions ( $\%$ of total fatty acids)

\begin{tabular}{|c|c|c|c|c|}
\hline Fatty acids & $\begin{array}{l}\text { Lipid extracted by chemical } \\
\text { method }\end{array}$ & $\begin{array}{l}\text { Lipid extracted by } \\
\text { enzymatic method }\end{array}$ & $\begin{array}{l}\text { Lipid from emulsified } \\
\text { fraction }\end{array}$ & $\begin{array}{l}\text { Lipid from heavy } \\
\text { fraction }\end{array}$ \\
\hline C14:0 (Myristic acid) & $2.84 \pm 0.01^{\mathrm{b}}$ & $4.26 \pm 0.29^{\mathrm{a}}$ & $3.20 \pm 0.09^{\mathrm{a}}$ & $1.79 \pm 0.02^{\mathrm{b}}$ \\
\hline C16:0 (palmitic acid) & $18.09 \pm 0.20^{\mathrm{a}}$ & $17.5 \pm 0.11^{\mathrm{a}}$ & $16.5 \pm 0.12^{\mathrm{a}}$ & $18.55 \pm 0.0^{\mathrm{a}}$ \\
\hline C17:0 (Margaric acid) & $4.18 \pm 0.04^{\mathrm{a}}$ & $5.96 \pm 0.5^{\mathrm{a}}$ & $4.16 \pm 0.2^{\mathrm{a}}$ & $2.67 \pm 0.04^{\mathrm{a}}$ \\
\hline C18:0 (Stearic acid) & $4.66 \pm 0.20^{\mathrm{b}}$ & $3.72 \pm 0.11^{\mathrm{b}}$ & $3.24 \pm 0.32^{\mathrm{b}}$ & $6.38 \pm 0.10^{\mathrm{a}}$ \\
\hline C18:1n7 (palmitoleic acid) & $2.82 \pm 0.05^{\mathrm{a}}$ & $2.13 \pm 0.20^{\mathrm{a}}$ & $2.03 \pm 0.10^{\mathrm{a}}$ & $2.85 \pm 0.20^{\mathrm{a}}$ \\
\hline C18:1n9c (Oleic acid) & $25.21 \pm 0.30^{\mathrm{a}}$ & $24.60 \pm 0.14^{\mathrm{a}}$ & $23.30 \pm 0.05^{\mathrm{a}}$ & $14.01 \pm 0.23^{\mathrm{a}}$ \\
\hline C20:1n9 (eicosenoic acid) & $1.37 \pm 0.20^{\mathrm{a}}$ & $1.05 \pm 0.02^{\mathrm{a}}$ & $1.25 \pm 0.32^{\mathrm{a}}$ & $2.18 \pm 0.02^{\mathrm{a}}$ \\
\hline C18:2n6 (Linoleic acid) & $0.90 \pm 0.20^{\mathrm{a}}$ & $0.90 \pm 0.01^{\mathrm{a}}$ & $0.63 \pm 0.01^{\mathrm{a}}$ & $0.73 \pm 0.01^{\mathrm{a}}$ \\
\hline C18:3n3 (Linolenic acid) & $2.66 \pm 0.20^{\mathrm{a}}$ & $4.55 \pm 0.10^{\mathrm{a}}$ & $3.55 \pm 0.10^{\mathrm{a}}$ & $2.57 \pm 0.04^{\mathrm{a}}$ \\
\hline C18:4n3 (stearidonic acid) & $1.31 \pm 0.15^{\mathrm{a}}$ & $1.74 \pm 0.04^{\mathrm{a}}$ & $1.30 \pm 0.04^{\mathrm{a}}$ & $0.07 \pm 0.21^{\mathrm{b}}$ \\
\hline C20:4n6 (arachidonic acid) & $2.26 \pm 0.04^{\mathrm{b}}$ & $6.00 \pm 0.01^{\mathrm{a}}$ & $5.50 \pm 0.11^{\mathrm{a}}$ & $2.54 \pm 0.01^{\mathrm{b}}$ \\
\hline C20:5n3 (Eicosapentaenoic acid) & $6.99 \pm 0.10^{\mathrm{a}}$ & $7.56 \pm 0.02^{\mathrm{a}}$ & $7.25 \pm 0.04^{\mathrm{a}}$ & $7.73 \pm 0.02^{\mathrm{a}}$ \\
\hline C22:5n3 (Docosapentaenoic acid) & $1.70 \pm 0.20^{\mathrm{a}}$ & $1.64 \pm 0.01^{\mathrm{a}}$ & $1.35 \pm 0.01^{\mathrm{a}}$ & $1.99 \pm 0.05^{\mathrm{a}}$ \\
\hline C22:6n3 (Docosahexaenoic acid) & $15.85 \pm 0.42^{\mathrm{b}}$ & $11.26 \pm 0.02^{\mathrm{b}}$ & $12.51 \pm 0.02^{\mathrm{b}}$ & $26.11 \pm 0.21^{\mathrm{a}}$ \\
\hline$\Sigma$ SFA & $29.77^{\mathrm{a}}$ & $31.44^{\mathrm{a}}$ & $27.10^{\mathrm{a}}$ & $29.33^{\mathrm{a}}$ \\
\hline$\Sigma$ MUFA & $29.40^{\mathrm{a}}$ & $27.78^{\mathrm{a}}$ & $26.58^{\mathrm{a}}$ & $19.04^{\mathrm{b}}$ \\
\hline$\Sigma$ PUFA & $31.67^{\mathrm{b}}$ & $33.65^{\mathrm{b}}$ & $32.09^{b}$ & $41.74^{\mathrm{a}}$ \\
\hline n3 & 28.11 & 26.75 & 25.96 & 38.47 \\
\hline n6 & 3.16 & 6.90 & 6.13 & 3.27 \\
\hline n6/n3 & 0.11 & 0.26 & 0.24 & 0.08 \\
\hline
\end{tabular}

\subsection{Fatty Acids Composition of the Fractions}

The fatty acid composition of mackerel lipid fractions is summarized in Table 3. Saturated fatty acids (C14:0, $\mathrm{C} 16: 0$ et le $\mathrm{C} 17: 0)$ levels were similar (3.24-4.66\%) in all lipid fractions $(\mathrm{p}>0.05)$, except the $\mathrm{C} 18: 0$ level which was high $(6.38 \%)$ in a lipid from sludge fraction. Concerning the Monounsaturated fatty acid (MUFA), there was a low content of $\mathrm{C} 18: \ln 9 \mathrm{c}(14.01 \%)$ in the lipid from sludge fraction, significantly different $(\mathrm{p}<0.05)$ than the other lipid fractions which varied from 23.30 to $25.21 \%$. The arachidonic acid level was a high level in the enzymatic lipid fraction $(5.50 \%)$ and the lipid from emulsified fraction $(6 \%)$ compared to the lipid obtained by chemical method $(2.26 \%)$ and the lipid from sludge $(2.54 \%)$. As for the high PUFA, the DHA (C22:6n3) level in lipid from sludge was 2-fold greater $(26.11 \%)$ than the lipid extracted from the other fractions. Levels of EPA (C20:5n3) and DPA (C22:5n3) were not significantly different in all lipid fractions. This allowed a high level of PUFA n3 (38.47\%) in the heavy fraction compared to levels in the other fractions, which varied from 26 to $28 \%$ $(\mathrm{p}<0.05)$. In the same order MUFA and PUFA n6 levels were significantly reduced in the heavy fraction.

Data are means with standard deviations of triplicate values. Values not sharing a common superscript differ significantly.

\section{Discussion}

The effect of enzyme concentrations indicated that increasing enzyme concentration increased the Degree of Hydrolysis. When the enzyme concentration increased from $3 \%$ to $5 \%$, the increases of $\mathrm{DH}$ were varied from $21 \%$ to $26 \%$. The increase in enzyme concentration (from 3 to $5 \%$ ) increased the protein yield because more enzyme molecules became associated with fish particles thus releasing more protein molecules into the system [19,20]. Benjakul and Morrissey [21] obtained similar results and indicated that the increase in the Alcalase enzyme concentration increased the overall proteolysis rate and the solubilization of protein. From the chemical point of view, the enzyme broke down the protein network, leading to lipid release. After the centrifugation of the slurry, two main supernatant lipid fractions were obtained. According to data in the Table 1, the increase of enzyme concentration did not modify significantly oil and emulsion fractions yield, but reduced significantly the sludge fraction yield. This may be due to the product inhibition present during the hydrolysis or to total cleavage of all the susceptible peptide bonds. The cleavage of protein bond in the heavy fraction (sludge) was high with the high concentration of enzymes and induced the reduction of the sludge yield.

The proximate chemical composition revealed a high protein content $(17.24 \%$ on the fresh basis) of the heavy fraction, resulting from an incomplete hydrolysis of crude proteins, which was not sufficient to release most of the lipids. That explained the significant level of lipid content (13.6\% on the fresh basis). The ash content $(4.17 \%$ and $3.24 \%$ ) of both crude mackerel head and the heavy fraction were not significantly different and were higher than the ash content of both lipid and emulsion fraction $(0.33 \%$ and $0.21 \%)$. This depends on the presence of bones in the first samples.

The lipid class analyzed in the fractions showed high level of triacylglycerol (97-95\%) both from the whole sample and the emulsified fraction (using the enzymatic 
extraction) with no significant difference and were comparable to lipids extracted using the chemical method (98\%). Polar lipids ranged within $2-5 \%$ in this fraction. Similar results were obtained on lipid fractions extracted from Atlantic salmon [2,12]. Furthermore, for the heavy fraction, a high amount of Phospholipids (52\%) and $48 \%$ of triacylglycerol was found. This may be explained by the fact that the PL, which forms with peptides some phospholipopeptidic complexes, would not be sufficiently hydrolyzed by proteases (Alcalase 2.4L). These complexes were found in the heavy fraction after the centrifugation of the slurry.

The fatty acid profile of oil fraction indicated similar composition for lipid extracted by solvent, lipid extracted by enzymes and for lipid of emulsified fraction. The difference appears with the lipid of heavy fraction. The analysis revealed that the Docosahexaenoic acid (DHA) was the dominant fatty acid in the heavy fraction, which was two times higher $(26.11 \%)$ than the other fractions and the lipid from whole fraction (solvent method). Lower level of oleic acid $(14.01 \%)$ could also be noticed in the heavy fraction compared to other lipid fractions who account for 23 to $25 \%$. This may be explained by the naturally high content of PUFA in phospholipids. According to authors, the PUFA, especially the DHA and the EPA were distributed in specific sites of fishes and esterified preferentially in phospholipids [22,23]. This could explain the high amount of DHA in the heavy fraction.

\section{Conclusion}

Fishes are recognized to contain essential fatty acids, particularly Docosahexaenoic acid (DHA) and Eicosapentaenoic acid (EPA), which are good for health. In this study, the enzymatic process was used to extract a fraction which was rich in PUFA, especially DHA. This heavy fraction was rich in phospholipids, partially or non-hydrolysed proteins and lipids contained a high level (two times) of DHA compared to the released oil and the oil of emulsified fraction. This fraction consisted in phospholipopeptidic complex with good chemical characteristics. DHA and EPA have been reported to have preventive effects on human coronary artery disease. Therefore, the heavy fraction could be suggested as a key component for a healthy diet in humans and could be used to supplement essential fatty acids in the human diet.

\section{Acknowledgements}

The Laboratory of Biomolecular Engineering (University of Lorraine, France) is gratefully acknowledged for its materiel and technical support. We would like to thanks to Carole Jeandel from Laboratory of Biomolecular Engineering, for providing technical assistance to the research.

\section{Conflicts of Interest}

The authors declare no conflict of interest.

\section{References}

[1] Jabeen F. and Chaudhry, A. S., "Chemical Compositions and fatty acid profiles of three freshwater fish species". Food Chemistry, 125(3):991-996. 2011

[2] Gbogouri, G. A., Linder, M., Fanni, J. and Parmentier, M., "Analysis of lipids extracted from salmon (salar) heads by commercial proteolytic enzymes". European Journal of Lipid Science and Technology, 9:766-775. 2006.

[3] Liaset, B., Lied, E. and Espe, M., "Enzymatic hydrolysis of byproducts from the fish-filleting industry; chemical characterization and nutritional evaluation". Journal of Science of Food and Agriculture, 80: 581-589. 2000.

[4] Middaugh, J. P., "Cardiovascular deaths among Alaskan natives", 1980-1986. American Journal of Public Health, 80: 282-285. 1990.

[5] Newman, W. P., Middaugh, J. P., Propst, M. T. and Roger, D. R., "Atherosclerosis in Alaska natives and non-natives". Lancet, 341:1056-1057. 1993.

[6] Hoffman, D. R. and Uauy, R., "Essentiality of dietary omega-3 fatty acid for premature infants: Plasma and red blood cell fatty acid composition”. Lipids, 27: 886-896. (1992).

[7] Bourre, J. M., "Développement du cerveau et des acides gras polyinsaturés ». Oléagineux Corps gras, Lipides, 3: 173-177. 1996.

[8] Ackman R.G., "Remarks of on official methods employing boron trifluoride in preparation of methyl ester of fatty acids of fish oils". Journal of the American Oil Chemists' Society, 75: 541-545. 1998.

[9] Kim, S. K. and Mendis, E., "Bioactive compounds from marine processing byproducts - A review". Food Research International, 39: 383-393. 2006.

[10] Maroon, J. C. and Bost, J. W., "w-3 Fatty acids (fish oil) as an anti-inflammatory: an alternative to non-steroidal antiinflammatory drugs for discogenic pain". Surgical Neurology., 65: 326-331. 2006.

[11] Belhaj, N., Desor F., Gleizes, C., Denis, F. M, Arab-Tehrany, E., Soulimani, R. and Linder, M., "Anxiolytic-Like Effect of a Salmon Phospholipopeptidic Complex Composed of Polyunsaturated Fatty Acids and Bioactive Peptides". Marine Drugs, 11: 4294-4317. 2013.

[12] Linder, M., Fanni, J. and Parmentier M., "Proteolytic extraction of salmon oil and PUFA concentration by lipases". Marine Biotechnology. 15; 70-76. 2005.

[13] Liaset, B., Juslshamn, K. and Epse, M., "Chemical composition and theoretical nutritional evaluation of the produced fraction from enzymatic hydrolysis of salmon frames with Protamex". Process Biochemistry, 38: 1747-1759. 2003.

[14] Oulai, T. L., Gbogouri, G. A., Brou, K. and Tano, K., "Enzymatic extraction and biochemical characterization of lipids from the mackerel (scomber scombrus) and jawfish (chrysichthys nigrodigitatus) eaten in cote d'ivoire". Journal of Global Biosciences, 6 (7): 5131-5143. 2017.

[15] AOAC, Official Methods of Analysis. 15th Ed., Association of Official Analytical Chemistry, Washington DC. 1997.

[16] Folch, J., Lees, M. and Stanley, G. H. S., "A simple method for the isolation and purification of total lipids from animal sources". Journal of Biology and Chemistry, 226: 497-509. 1957.

[17] Idouraine, A., Kohlhepp, E. A. and Webber, C. W., "Nutrient constituents from eight lines of naked seed squash". Journal of the Agricultural and Food Chemistry, 44: 721-724. 1995.

[18] AOAC, Official Methods of Analysis. (15th ed.) Arlington, VA: AOAC, Sec. 969.33 "Fatty acids in oils and fats, preparation of methyl esters (pp. 963-964)", and Sec. 963.22 "Methyl esters of fatty acids in oils and fats, gas chromatographic method (pp. 964-965)". 1990.

[19] Ramakrishnan, V. V., Ghaly, A. E., Brooks, M. S. and Budge, S. M., "Extraction of Proteins from Mackerel Fish Processing Waste Using Alcalase Enzyme". Journal of Bioprocessing and Biotechniques, 3 (2): 1-9. 2013.

[20] Gbogouri, G. A., Linder, M., Fanni, J. and Parmentier, M., "Influence of Hydrolysis Degree on the Functional Properties of Salmon Byproducts Hydrolysates". Journal of Food Science, 69: C615-C622. 2004.

[21] Benjakul, S. and Morrissey, M. T., "Protein Hydrolysates from Pacific Whiting Solid Wastes. Journal of Agricultural and Food Chemistry, 45: 3423-3430. 1997. 
[22] Body, D. R. and Vlieg, P., Distribution of the lipids classes and éicosapentaenoic (20:5 n-3 docosahexaénoic (22:6n-3) acids in different sites in blue mackerel (Scomber australasicus) filets". Journal of Food Science, 54: 569-572. 1989.
[23] Gbogouri, G. A. "Co-valorisation des protéines et des lipides riches en lécithine et en acides gras polyinsaturés Omega 3 à partir de têtes de saumon (salmo salar) par hydrolyse enzymatique". Thèse 161p. 2005. 